\title{
An interview with Dean Atta
}

Sukhwant Dhaliwal and Dean Atta*

*Correspondence: infodeanatta@gmail.com

SD: Can you tell us a bit about yourself and how you got into writing poetry?

I am a black, queer, working-class writer from London, with Greek Cypriot and Jamaican heritage. I got into writing poetry as a way to tell my story. Spoken word was what first got me writing poetry; I wrote in order to get up and perform it. I grew up performing in theatre productions in London's West End, so I had the confidence to go in front of an audience. My first poetry gig was at The Poetry Cafe in Covent Garden when I was 17. Once you go to one event, you quickly find out about all the others.

There are so many more spoken word nights around London and the UK now compared to when I started in 2003 , and you can find so much spoken word online. Now poets can build up an online audience without ever performing on stage. For me poetry was a part of my social life, as much as it was an aspiration of something I'd like to do professionally. I held onto this aspiration whilst reading Philosophy and English at the University of Sussex, where I kept on writing and performing in my spare time.

Poetry is now my career. I published my first collection of poems in 2013 and completed a Writer/Teacher MA at Goldsmiths College, University of London in 2014. Alongside writing and performing, I now teach poetry workshops in education settings and in the community.

SD: What are the sorts of issues that you touch on / tackle in your poetry? 
I write about race and sexuality a lot. I also write about family and relationships, but in terms of what one would call issues, it's mostly the aforementioned. My debut poetry collection is called I Am Nobody's Nigger, the title taken from a poem I wrote about my relationship with Hip Hop and the historical and current use of the N-word. Other prominent poems from that collection include "Young, Black and Gay" which is a proud poem about defining oneself, and "Rome is Eternal" which is about using the dating app Grindr on a visit to Italy. "Revolution" which is featured in this Issue is also from this collection and is one of the first poems I wrote when I was 17. I published the collection when I was 28 and the poems within it cover a decade of my life from 17 to 27.

SD: The three poems that we are featuring in this Special Issue of Feminist Dissent touch on quite different but presumably interconnecting issues that connect insofar as they link back to your own sense, location, and representation of yourself. Could you tell us about these three poems, how they came about, and how or if they are connected?

"Revolution" is one of my first poems and is influenced by what I was reading and listening to at the time: poets like Gil Scott-Heron, Maya Angelou, and Ursula Rucker, music by Bob Marley, Nirvana, and Tupac Shakur, as well as the bible verses, hymns, and patois heard in my childhood. I went to Church of England primary and secondary schools, however, both schools were multicultural and there were people of many faiths. London slang influenced by Jamaican patois was spoken amongst students and some of this has made its way into the poem. At A Level, I studied Drama, English, and Sociology, and I think all three subjects influenced this poem in its performative nature, use of rhetoric, and in the themes covered in the poem, such as conflict and community, and the need for intergenerational dialogue. 
"I Come From" is a poem I wrote during my MA at Goldsmiths; it was written to be used in schools to model a workshop I lead where I get students to write about where they come from. I do not say Britain, Cyprus, or Jamaica, but allude to these places with food: "I come from shepherd's pie and Sunday roast, / jerk chicken and stuffed vine leaves." I've found that food is a great starting point when asking young people to write about culture. Rather than say I'm British I say, "I come from a British passport". I mention the rainbow flag and the Union Jack to put sexuality on par with national identity, because being part of the LGBT community has been such a strong part of my identity and I have experienced solidarity with LGBT people around the world. The poem ends with these lines: "I come from my own pen but I see people torn apart like paper, / each a story or poem that never made it into a book."। say this to acknowledge my privilege as someone able to freely tell their own story.

"The Black Flamingo" is one of my newest poems and was inspired by a trip to Cyprus to visit my grandparents. Whilst I was there, a black flamingo arrived on the island and was on the news several times a day. My grandfather kept the TV on the news channel most of the time. I saw the image of the black flamingo on TV a lot during this visit, and not only did my grandfather speak about it, but also when I was in cafes and on the beach, it was a topic of conversation amongst holiday makers and locals alike.

I remembered trips to Cyprus as a teenager when my hair was in locs, and people would shout "Bob Marley" at me on the beach and in the street and even touch my hair without permission. Wearing locs was a way I felt connected to my Jamaican heritage, although my Jamaican grandmother did not approve of it at first. I no longer have that hairstyle, but hearing everyone talk about the black flamingo I was reminded of what it was like when they were talking about me. 
I also think of the black flamingo as a metaphor for being black and queer - it represents an intersectional identity. My grandfather died last year and there were many things unspoken between us. I never came out to him. I felt he struggled to understand my blackness and I was not sure if he would be able to accept my queerness.

\section{To cite this article:}

Atta, D. and Dhaliwal, S. (2019) An Interview with Dean Atta, Feminist Dissent, 4, pp. 279-282. Retrieved from:

https://doi.org/10.31273/fd.n4.2019.414 